\title{
IN-CLASSROOM TEACHING IS HERE TO STAY-AT LEAST FOR STUDENTS IN COMPUTER AND INFORMATION SYSTEMS
}

\author{
Paul J. Kovacs, Robert Morris University, kovacs@rmu.edu \\ Lisa Kovalchick, California University of Pennsylvania,kovalchick@calu.edu \\ Alan Peslak, Penn State University, arp14@psu.edu \\ Wenli Wang, Robert Morris University, wangw@rmu.edu
}

\begin{abstract}
Is online education a continuing trend or a temporary hype? Is online education for students in all subject areas? This study surveyed 245 students enrolled in Computer and Information Systems (CIS) courses at two U.S. universities. The generalizable results show that 1) CIS students perceive that on-ground instructions (both completely on-ground and on-ground with online supplement) provide the best letter grade as well as the best collaboration; 2) There is a significant negative relationship between CIS students' preparedness for online courses and their preference of offering less online courses; and 3) There is no relationship between CIS students' learning style (i.e., by seeing, listening, reading, or doing) and their perceived overall effectiveness of online courses. This research suggests that on-ground learning is preferred-at least for CIS students in this survey. Students may increase their interests in online courses if they are better prepared for this method of learning.
\end{abstract}

Keywords: Online Learning, Distance Learning, Web-Based Learning, CIS Curricula

\section{INTRODUCTION}

Ten years ago, all Computer and Information Systems (CIS) courses at the author's universities were taught face-toface in the classroom. However, during the past ten years advances in communication technologies and media-rich additions of the Internet have permitted alternatives to this traditional classroom teaching and learning format. This has lead university administrators to incorporate various delivery formats as a critical component of their long-term strategy to offer education to increasing numbers of students at less expense than conventional classroom education. This has resulted in alternative methods for CIS faculty to deliver course content to their students, as well as, to provide students with choices in their learning environment. Recently, at the author's universities an academic division has been created dedicated to serving and supporting the success of online students and complete degrees are now offered in the online delivery method.

Computer and Information Systems courses can present unique challenges to the delivery of course content, particularly, in the online format. For example, courses in CIS curricula that involve instruction in computer programming languages require a hands-on approach and extensive drill and practice. Other CIS courses entail theoretical stand-alone educational software programs that may have a significant Internet-based instructional component. As a result, these delivery methods, specifically, the online format, raises important questions that must be addressed as to how they impact student learning and student perceptions of learning in CIS courses.

Results of the previous study by two of the authors [11] found that students taking CIS courses rated the effectiveness of hybrid/partially online courses as higher than that of completely online courses. Additionally, a relationship was found between taking an online class in the past and preference for the online delivery method. Although taking an online class does not directly influence a student to take another online class, students who have not taken an online class are discouraged from trying the online format. Although not reported in the study, the data indicated that age and gender have no impact with regard to rating of effectiveness of on-ground education.

To extend the previous study, this research aims to answer the following research questions:

1. Which delivery method (i.e., on-ground, online, hybrid/partially online, and on-ground with online supplement) do students perceive as providing the best letter grade, best collaboration, or both in regard to CIS courses? 
2. Is a student's dislike for online courses influenced by his/her preparedness for online courses?

3. Does a relationship exist between a student's learning style (i.e., by seeing, by listening, by reading, or by doing) and his/her perceived overall effectiveness of online courses?

\section{DEFINITION OF LEARNING FORMATS}

For the purposes of this research, the author's universities define on-ground courses as "face-to-face" instruction in which 100 percent of the content is delivered in the classroom with no Web-based server software technology. Conversely online courses are defined as those in which 100 percent of the course content is delivered using Webbased server software with no face-to-face instruction. A course delivered in the hybrid/partially online or the "blended" learning format includes both face to face and on-line instruction in which between 30 percent and 80 percent of the course content incorporates a course management system and virtual learning environment. Finally an on-ground course with online supplement can incorporate a number of Web-based supplements such as blogs, podcasting, "wikis", threaded discussions and Web-based assignments and examinations.

\section{STUDIES RELATING TO THE VARIOUS DELIVERY METHODS}

A comprehensive study undertaken by the Babson Survey Research Group supported by the Sloan Consortium and Pearson tracked ten years of online education in the United States [1]. The study sought the opinions of chief academic officers and received responses from more than 2,800 colleges and universities. When this report series was initiated in 2002, less than one-half of all higher education institutions reported that online education was critical to their long-term strategy. In 2012, that number is now close to 70 percent. The survey asked respondents to characterize their face-to-face, blended, and online learning by the level of the course (undergraduate, graduate, non-credit, etc.). Similarly, respondents were asked to characterize their face-to-face, blended, and online program offerings by level and discipline.

The study found that online enrollments have continued to grow at rates far in excess of the total higher education student population and the number of students taking at least one online course continued to increase at a robust rate. There were 572,000 more online students in the fall of 2011 than in the fall of 2010 for a new total of 6.7 million students taking at least one online course. This is a slightly larger numeric increase as seen from the fall of 2009 to the fall of 2010. It also is very close to the average increase seen for each of the last nine periods (which produced an average growth of 568,000 students per year). However, although the number of online courses and programs continue to increase, the perception of this delivery method by faculty has decreased. In the most recent year of this study (2012), only 30.2 percent of faculty accepts the legitimacy and value of the online delivery method. This rate is lower than the rate recorded in 2004. In addition to the lack of faculty acceptance, the report found concerns about the need for more discipline on the part of online students as well as lower retention rates [1].

Finally, in 2003, it was found that 57.2 percent of academic leaders rated the learning outcomes in online education as the same or superior to those in face-to-face. And in 2012 that number has risen to 77.0 percent. However, a minority (23.0\%) of the respondents believe the learning outcomes for online education are inferior to those of faceto-face instruction and institutions with online offerings have a much more favorable opinion of the relative learning outcomes for online courses than do those at institutions with no online offerings.

Additional studies indicate that performance is the same, regardless of whether a course is taken face to face or online. Daymont and Blau [3] found that undergraduate students perform equally well in both online and traditional sections. The study considered particular factors including class and major and found that the online students, while doing equally well, did not do better than their counterparts in traditional classrooms.

$\mathrm{Lu}, \mathrm{Yu}$ and Liu [12] found that none of the factors, except ethnic groups, showed any significant impact on students' learning performance in graduate Management Information Systems classes. Another study by Kleinman and Entin [10] contrasted online and traditional classroom teaching from both the instructor and student perspectives as related to two sections of an introductory Visual Basic programming course. While the online students were more positive about the value of the course, no difference in performance could be found between the online and the traditional methods of delivery. A study of online instruction examined the traditional sections of Computer Literacy versus WebCT sections and found retention and grade distribution to be similar for both groups [17]. Conversely, research 
involving an analysis of student performance in online Computer Science courses concluded that Computer Science students enrolled in a traditional networking course outperformed the Computer Science students enrolled in the online section of the course [13].

Several studies indicated mixed results. Analysis of the data of a study in a Management Information Systems course indicated a significant difference between students grades in a traditional setting ( 85 percent) versus student grades in an online setting (81 percent) [19]. Similar results were found regarding an entry-level programming course: student grades in the online section averaged 78 percent while student grades in the traditional section averaged 84 percent. Another, more comprehensive study that involved seven courses in Computer Science and Information Systems showed mixed results: in some courses, online students have not performed as well as traditional students [20]. The authors found that in four upper-level courses (Programming Languages, Survey of Algorithms, Computer Organization II and Theory and Implementation of Programming Languages) taken by Computer Science majors, no significant differences in performance were found. However, three courses (Introduction to Programming Visual Basic, Management Information Systems and Database Systems) taken by students from many majors and minors showed significant differences in student performance. The authors concluded that some students taking an online course (who are academically equal to students taking a traditional course) are satisfied to trade a low grade for convenience. Additionally, students taking a course outside of their major do not want to spend much time on the course and will choose the online format because attendance is not required.

Zhao, Lei, Yan and Tan [22] investigated factors that affect "effective" distance education. The empirical findings varied greatly and were not found to be significantly different from those of traditional instructional methods. However, the findings also offered evidence that not all content is appropriate for distance education and some students may not be able to benefit from the distance education delivery method. Although students' perceptions of the advantages of online education may be positive, there are also disadvantages for students who have never taken an online course or who have little computer experience. A study by Wang, Newlin and Tucker [21] found that many students taking Web-based courses expressed feelings of intense anxiety about the technology. In addition, it was found that there are disadvantages in online courses for individuals who require a great deal of structure. Online courses are often self-paced and students who lack self-discipline may struggle. In their study Howland and Moore [9] found that students' expectations were a determining influence on their online course experience and strategies. They reported that self-management, self-monitoring, and motivations are key factors for success in online classes. Picciano [15] and Song, Singleton, Hill, and Koh [18] found somewhat different results. Their research found that lack of interaction, persistence or both can affect the student's perception of how well he or she may or may not feel about his/her performance in an online class. While interaction does affect learning outcome to some extent, this is an area in need of further study.

A study by Dobbs, Waid, and Carmen [4] measured students' perceptions of online course experiences. The participants of the study were 100 students who were attending "face-to-face" classes and 180 students who were attending online classes. The authors discovered that more students perceived the "face-to-face" classes to be easier than online classes. Student views about online education varied greatly between those who had never taken an online class and those who had actually taken such courses. Those students with no online class experience believed that the faculty would have low expectations but students who had taken at least one online course felt that high expectations were common with faculty. The study also found that the acceptance of online education increased as the number of online courses taken increased. In another study, Hannay and Newvine [8] reported that students must possess greater discipline to succeed in an online course. Students who had never taken an online course were not confident that they could do as well in an online course as they would in an on-ground, "face-to-face", course. Additionally, students were skeptical about the opportunity of interaction with classmates in an online course and thought the online course would not cover the material in the same magnitude as the "face-to-face" course.

In their study involving undergraduate management courses, Drennan, Kennedy and Pisarski [6] found that research subjects thought it was important to achieve a balance between the use of "face-to-face", lectures and emerging technologies. In another study involving undergraduate accounting students, researchers found that the blended or hybrid or approach was superior to course content delivered entirely online. Specifically, the researchers determined that using technology as an exclusive course delivery method was considered insufficient [7]. 
A recent comprehensive 12-year experimental and quasi-experimental study utilizing meta-analysis conducted by the U. S. Department of Education found that a blend of online and "face-to-face" instruction has been more effective, which provides a rationale for the effort required to design and implement blended approaches [14]. This research also indicated that, despite what appears to be strong support for online learning applications, the studies in this meta-analysis do not demonstrate that online learning is superior as a medium. In many of the studies that involved a preference for online learning, the online and classroom conditions differed in terms of time spent, curriculum and pedagogy.

Finally in a study involving online education and learning styles, Downing and Chim [5] found that preference for an active learning style has a positive effect on students' performance. Smith [17] identified two major factors for successful online learning: (a) self-management of learning and (b) comfort with eLearning. Butler and Pinto-Zipp [2] further identified the three strongest preferences of the online learners: convenience, time management and interactivity.

\section{METHODS AND PROCEDURES}

The participants of the study were students at the undergraduate and graduate level enrolled in Computer and Information Systems courses at two universities. One university is state-owned with a total enrollment of 8,243 students in the fall of 2014. The other university is a private institution with an enrollment of 5,359 undergraduate and graduate students in the fall of 2014. Both of the universities' CIS degree programs are accredited by ABET.

To answer the research questions, an online survey instrument was used that consisted of 34 close-ended questions. This survey was administered during Academic Years 2010 to 2011 and again in 2011 to 2012. The respondents of the private university consisted of undergraduate, graduate and post-graduate students; whereas, the respondents from the public university consisted only of undergraduate students. A total of 245 students responded to the survey. The students completed the survey online while enrolled in a CIS course delivered in an on-ground, online, hybrid/partially online, or on-ground course with online supplement format. The students submitted their anonymous results into an electronic database and the results were analyzed using SPSS statistical software. Statistical frequencies and statistical tests were used to answer the research questions posed in the introduction section

Since the sample is composed of students in both public and private universities, the demographic information (age, gender, etc.) is comparable to the general of the CIS student population in the U.S., and one sub-sample from one university that has students from the undergraduate, graduate, and post-graduate levels and our preliminary research shows there is no significant difference among these levels, the results below from this research can be generalized to the general CIS students in the U.S.

\section{RESEARCH RESULTS}

The 2011 study [11] asked the research question "Which delivery method (i.e., on-ground, online, hybrid/partially online) do students perceive as providing the best learning in regard to CIS subject areas?" As shown in Table 1, the 2011 study found that overall, CIS students perceived on-ground course delivery as providing the best learning.

Table 1. Best Learning by CIS Subject Area and Method of Delivery

\begin{tabular}{|l|r|r|r|}
\hline Perceived BEST Learning & $\begin{array}{c}\text { Completely } \\
\text { Online }\end{array}$ & $\begin{array}{c}\text { Hybrid/Partially } \\
\text { Online }\end{array}$ & $\begin{array}{c}\text { On-ground } \\
\text { Instruction }\end{array}$ \\
\cline { 2 - 4 } & Sub table N \% & Sub table N \% & Sub table N \% \\
\hline Software Development & $11.0 \%$ & $18.4 \%$ & $70.6 \%$ \\
\hline Network Administration & $11.8 \%$ & $19.2 \%$ & $69.0 \%$ \\
\hline Web Development & $15.9 \%$ & $22.0 \%$ & $62.0 \%$ \\
\hline Multimedia-Graphics & $14.3 \%$ & $24.1 \%$ & $61.6 \%$ \\
\hline Office Productivity & $29.4 \%$ & $23.3 \%$ & $47.3 \%$ \\
\hline IT Project Management & $11.4 \%$ & $22.9 \%$ & $65.7 \%$ \\
\hline Systems Analysis & $11.8 \%$ & $19.2 \%$ & $69.0 \%$ \\
\hline Certification Courses & $17.1 \%$ & $18.4 \%$ & $64.5 \%$ \\
\hline
\end{tabular}




\begin{tabular}{|l|r|r|r|}
\hline Operating Systems & $18.4 \%$ & $20.8 \%$ & $60.8 \%$ \\
\hline Database Management & $10.2 \%$ & $20.8 \%$ & $69.0 \%$ \\
\hline Business Intelligence & $13.1 \%$ & $22.4 \%$ & $64.5 \%$ \\
\hline
\end{tabular}

As shown in Table 1, with regard to the best learning, on-ground instruction remained the preferred method for all course groupings with an average preference of $64 \%$.

In this follow-up study, the authors examined the strength of on-ground preference by analyzing two other measures. Thus, the first research question for this study asked "Which delivery method (i.e., on-ground, online, hybrid/partially online, on-ground with online supplement) do students perceive as providing the best letter grade, the best collaboration, or both in regard to CIS subject areas?" In order to answer this question, the survey instrument asked the 245 respondents to select the delivery method that they felt provided the best letter grade for each grouping of CIS-related topics; it also asked these respondents to select the delivery method that they felt provided the best collaboration for each grouping of CIS-related topics. The available CIS groupings were: Software Development/ Programming, Network Administration/Security, Web Design/Web Graphics, Office Productivity Software, IT Project Management, Systems Analysis \& Design, Certification Courses (e.g., A+, N+), Operating Systems and Database and Business Intelligence (i.e., Data Warehousing, Data Mining). The results from these questions are summarized in Tables 2 and 3.

Table 2. Best Letter Grade by CIS Subject Area and Method of Delivery

\begin{tabular}{|l|r|r|r|r|}
\hline $\begin{array}{c}\text { Perceived Best Letter } \\
\text { Grade }\end{array}$ & $\begin{array}{c}\text { Completely } \\
\text { Online }\end{array}$ & $\begin{array}{c}\text { Hybrid/Partially } \\
\text { Online }\end{array}$ & $\begin{array}{c}\text { Completely } \\
\text { On-ground }\end{array}$ & $\begin{array}{c}\text { On-ground } \\
\text { with Online } \\
\text { Supplement } \\
\text { Sub table N \% }\end{array}$ \\
\cline { 2 - 5 } & Sub table N \% & Sub table N \% & Sub table N \% & $19.2 \%$ \\
\hline Software Development & $14.3 \%$ & $17.6 \%$ & $49.0 \%$ & $19.2 \%$ \\
\hline Network Administration & $15.1 \%$ & $19.6 \%$ & $46.1 \%$ & $17.6 \%$ \\
\hline Web Development & $20.4 \%$ & $19.6 \%$ & $42.4 \%$ & $17.1 \%$ \\
\hline Multimedia-Graphics & $18.8 \%$ & $21.2 \%$ & $42.9 \%$ & $16.7 \%$ \\
\hline Office Productivity & $24.9 \%$ & $17.6 \%$ & $40.8 \%$ & $19.0 \%$ \\
\hline IT Project Management & $14.7 \%$ & $18.4 \%$ & $46.9 \%$ & $19.6 \%$ \\
\hline Systems Analysis & $14.3 \%$ & $20.0 \%$ & $46.1 \%$ & $18.4 \%$ \\
\hline Certification Courses & $18.4 \%$ & $15.1 \%$ & $46.9 \%$ & $20.0 \%$ \\
\hline Operating Systems & $18.0 \%$ & $19.2 \%$ & $44.5 \%$ & $19.6 \%$ \\
\hline Database Management & $14.7 \%$ & $16.7 \%$ & $48.6 \%$ & $45.7 \%$ \\
\hline Business Intelligence & $17.1 \%$ & $17.6 \%$ & & \\
\hline
\end{tabular}

As shown in Table 2, with regard to expected letter grade, similar to Table 1, on average $64 \%$ of respondents expected a higher letter grade with instruction that was: on-ground or on-ground with online supplement. This is most likely due to an expectation of greater instructional value from these traditional methods.

Table 3. Best Collaboration by CIS Subject Area and Method of Delivery

\begin{tabular}{|l|r|r|r|r|}
\hline \multirow{2}{*}{$\begin{array}{c}\text { Perceived BEST } \\
\text { Collaboration }\end{array}$} & $\begin{array}{c}\text { Completely } \\
\text { Online }\end{array}$ & $\begin{array}{c}\text { Hybrid/Partially } \\
\text { Online }\end{array}$ & $\begin{array}{c}\text { On-ground } \\
\text { Instruction }\end{array}$ & $\begin{array}{c}\text { On-ground } \\
\text { with Online } \\
\text { Supplement }\end{array}$ \\
\cline { 2 - 5 } & Sub table N \% & Sub table N \% & Sub table N \% & Sub table N \% \\
\hline Software Development & $6.1 \%$ & $20.4 \%$ & $49.8 \%$ & $23.7 \%$ \\
\hline Network Administration & $6.1 \%$ & $21.6 \%$ & $49.8 \%$ & $22.4 \%$ \\
\hline Web Development & $7.3 \%$ & $26.1 \%$ & $45.7 \%$ & $20.8 \%$ \\
\hline Multimedia-Graphics & $7.3 \%$ & $25.7 \%$ & $45.3 \%$ & $21.6 \%$ \\
\hline Office Productivity & $11.4 \%$ & $25.3 \%$ & $44.9 \%$ & $18.4 \%$ \\
\hline IT Project Management & $6.9 \%$ & $20.4 \%$ & $49.8 \%$ & $22.9 \%$ \\
\hline Systems Analysis & $7.3 \%$ & $20.0 \%$ & $47.3 \%$ & $25.3 \%$ \\
\hline
\end{tabular}




\begin{tabular}{|l|r|r|r|r|}
\hline Certification Courses & $9.0 \%$ & $21.2 \%$ & $46.9 \%$ & $22.9 \%$ \\
\hline Operating Systems & $8.2 \%$ & $23.3 \%$ & $47.3 \%$ & $21.2 \%$ \\
\hline Database Management & $4.9 \%$ & $20.4 \%$ & $50.6 \%$ & $24.1 \%$ \\
\hline Business Intelligence & $7.8 \%$ & $21.2 \%$ & $49.0 \%$ & $22.0 \%$ \\
\hline
\end{tabular}

As shown in Table 3, not unexpectedly, an even higher percentage of respondents, on average $70 \%$ of the respondents, saw higher potential collaboration with the on-ground instructional options.

Next, the authors 2011 study [11] asked the research question, For each instructional method (i.e., online, hybrid/partially online, on-ground) should your school Offer More, Keep Offerings the Same or Offer Less courses that use a particular instructional method? Table 4, shows the results for on-ground versus online preferences.

Table 4. Course Offerings Preferences and Method of Delivery

\begin{tabular}{|l|l|r|}
\hline \multicolumn{2}{|l|}{} & Sub table N \% \\
\hline \multirow{4}{*}{ Add On-ground } & Offer More Courses & $41.2 \%$ \\
\cline { 2 - 3 } & Keep Course Offerings the Same & $53.5 \%$ \\
\cline { 2 - 3 } & Offer Less Courses & $5.3 \%$ \\
\hline \multirow{4}{*}{ Add Online } & Offer More Courses & $35.9 \%$ \\
\cline { 2 - 3 } & Keep Course Offerings the Same & $39.6 \%$ \\
\cline { 2 - 3 } & Offer Less Courses & $24.5 \%$ \\
\hline \multirow{3}{*}{$\begin{array}{l}\text { Add Partial Online } \\
\text { w/Supplement }\end{array}$} & Offer More Courses & $50.6 \%$ \\
\cline { 2 - 3 } & Keep Course Offerings the Same & $39.6 \%$ \\
\cline { 2 - 3 } & Offer Less Courses & $9.8 \%$ \\
\cline { 2 - 3 } & Offer More Courses & $53.9 \%$ \\
\cline { 2 - 3 } & Keep Course Offerings the Same & $39.6 \%$ \\
\cline { 2 - 3 } & Offer Less Courses & $6.5 \%$ \\
\hline
\end{tabular}

As is apparent from Table 4, online courses have the highest percentage of preference for course reduction. In this follow-up study, the authors were interested in extending the question and hypothesized that this dislike for online courses may be influenced by preparation for online courses. Thus, the second research question for this study asked "Is a student's dislike for online courses influenced by his/her preparation for online courses?" In order to answer this research question, in addition to students' preference for more online courses, the survey instrument asked "How would you rate your preparedness (to take an online course) prior to taking your online course?" Possible ratings consisted of: extremely unprepared, somewhat unprepared, neither unprepared nor prepared, somewhat prepared or extremely prepared. Table 5, shows a regression analysis that measures levels of preparedness versus preference for more online courses.

Table 5. Regression Analysis Measuring Levels of Preparedness versus Preference for Offering Less Online Courses

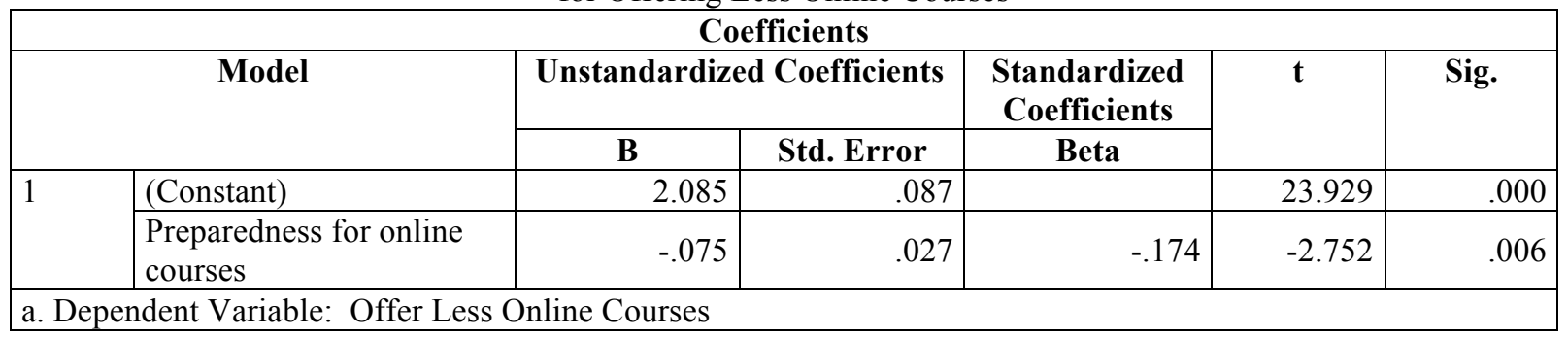

As shown in Table 5, a highly significant negative relationship exists (coefficient $=-0.075, \mathrm{p}<.006$ ) between preference for offering less online courses and preparedness for online courses. Students' unpreparedness is a significant factor for their preference of offering less online courses. This may suggest that helping students better prepare for online courses may increase their likes for online courses... 
For this follow-up study, our final research question asked "Does a relationship exist between a student's learning style (i.e., by seeing, by listening, by reading, by doing) and their perceived overall effectiveness of courses taught completely online?" In order to answer this research question, the survey instrument asked the 245 respondents to complete the following sentence "I learn best ..." Possible responses included: by seeing (visually), by listening, by reading, and by doing (hands-on). In addition, the survey asked the 245 respondents to indicate their perceived overall effectiveness of courses taught completely online. Possible responses included: very effective, effective, somewhat effective, somewhat ineffective, ineffective and very ineffective. Table 6, provides a cross tabulation of learning style and perceived overall effectiveness of courses taught completely online.

Table 6. Cross Tabulation of Learning Style and Perceived Effectiveness of Courses Taught Completely Online 22) Learning Style Recoded Numeric * 8) Overall Effectiveness - Completely Online Cross Tabulation

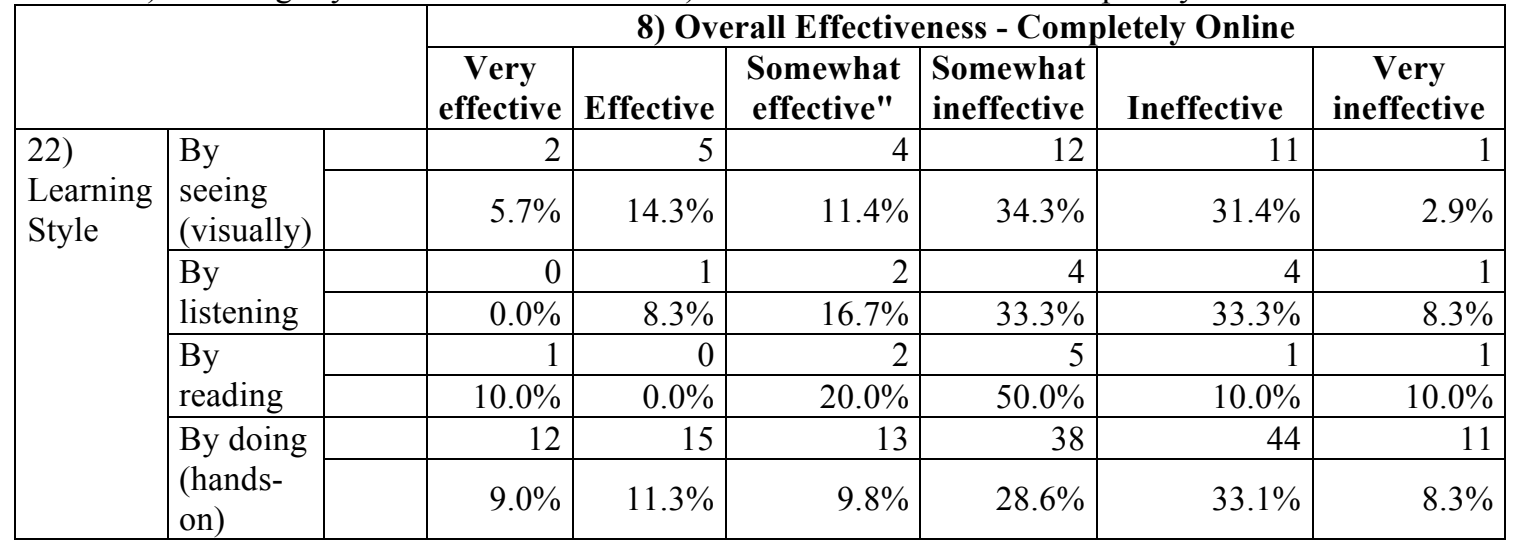

As Table 6 indicates, there is little difference between perceived levels of effectiveness for online courses based on preferred learning style. A Chi-square analysis displayed in table 7 shows no significant difference between preferences for learning style and perceived overall effectiveness of online courses. This is an important finding and suggests that online effectiveness is not impacted by learning style.

Table 7. Chi-Square Tests

\begin{tabular}{|l|r|r|r|}
\hline & \multicolumn{1}{|c|}{ Value } & \multicolumn{1}{c|}{ df } & \multicolumn{1}{c|}{$\begin{array}{c}\text { Asymp. Sig. } \\
\text { (2-sided) }\end{array}$} \\
\hline Pearson Chi-Square & $8.581^{\mathrm{a}}$ & 15 & .898 \\
\hline Likelihood Ratio & 11.083 & 15 & .747 \\
\hline Linear-by-Linear Association & .038 & 1 & .846 \\
\hline N of Valid Cases & 190 & & \\
\hline $\begin{array}{l}\text { a. } 16 \text { cells }(66.7 \%) \text { have expected count less than 5. The minimum expected } \\
\text { count is .74. }\end{array}$
\end{tabular}

\section{CONCLUSIONS}

The present research surveyed undergraduate, graduate and post-graduate students enrolled in Computer and Information Systems courses at two universities to examine the questions: (1) Which delivery method (i.e., onground, online, hybrid/partially online, on-ground with online supplement) do students perceive as providing the best letter grade and best collaboration in regard to CIS subject areas? (2) Is a student's dislike for online courses influenced by their preparation for online courses? (3) Does a relationship exist between a student's learning style (i.e., by seeing, by listening, by reading, by doing) and their perceived overall effectiveness of courses taught completely online?

In regard to the first research question, the majority of respondents expected a higher grade and better collaboration with instruction that was: on-ground or on-ground with online supplement. This finding falls in line with the 2011 study that found that the majority of respondents felt that on-ground instruction provided the best learning for CIS courses 
In regard to the second research question, a relationship exists for those who were more prepared and preference for online courses. In order to successfully participate in an online course, a student must be well organized, selfmotivated, and possess a high degree of time management skills. This may suggest that, if students in this survey were first taught techniques in organization, time management and preparation, online courses could become a more preferred learning method.

The result to the third research question shows that no significant relationship between students' preference for learning style and the perceived overall effectiveness of online courses.

The inherent content of CIS courses must be considered in light of the current research findings. The current study surveyed students who were specifically enrolled in CIS programs. Since CIS programs involve content that is quantitative and technically-oriented, some students may have difficulty comprehending such content in an online format. As a result, the technical nature of such course content may explain why CIS students in the current study did not prefer an online method of course delivery. For instance, when a CIS student takes a programming course, it is important for the student to have a programming environment set up properly, so that the student can follow the instructions for programming. Without a proper environment, a student cannot exercise specific programming instructions. When teaching programming courses online, such as Visual Basic and Advanced Visual Basic, the authors now provide online tutorials regarding how to set up the programming environment, as well as clear step-bystep instructions with screenshots describing how to start programming, save files, and submit zipped directories for programs, etc. With such clear guidance, fewer students have difficulties and for those who have problems, the authors have ensured sufficient and timely email interactions with the students to make certain they progress in the course. Timely grading of early module programming assignment is critical to capture students' potential problems and hence provide them timely guidance to make sure they do not get frustrated or lose confidence in the online learning environment.

Another approach to building interaction into online CIS courses is the inclusion of an online discussion forum into the course. One author uses online forums as a place for students to ask questions and interact with the professor. The forum acts as type of online office; however, unlike a traditional office, it allows all students to view each other's questions and interactions with the instructor. The forum also allows students to answer one another's questions and interact with each other, similar to how they would in an on-ground classroom environment.

At the time of the survey, the author's universities did not have a training unit on campus for on-line course development that addressed the needs of faculty and students. Since then an academic division has been created dedicated to serving and supporting the success of the on-line format by emphasizing technical and pedagogic skill development for faculty, assessing faculty and student training needs prior to the training, and providing ongoing resources and support mechanisms following the training. If such support were in place before the time of this survey, the results may have been different - a larger number of students may have felt more comfortable with online teaching. In addition to university-level leadership and support in online education, the CIS department at one of the universities involved in this study also created an online quality committee which specifically addresses the issue of improving the pedagogy for online education. For instance, it has chosen model online courses for different CIS content areas, such as theory-based course vs. programming-based course, to demonstrate good practices among faculty. Sufficient contact hours with the students in online courses are also emphasized to ensure the support of students' needs.

Finally, although the CIS courses taught in the online format may be selected by a self-disciplined student, it may be an inappropriate learning environment for a more dependent student. Therefore, those designing CIS courses in the on-line format may need to assess whether their intended students have dedication, commitment, time management skills and self-motivation to take such a course. Many students in this study may have selected the traditional classroom method of delivery because they have less difficulty with this type of learning and may require a high degree of intervention from the instructor.

\section{REFERENCES}

1. Allen, I. E., \& Seaman, J. (2013), Changing Course: Ten Year of Tracking Online Education in the United States. The Sloan Consortium. Retrieved February 11, 2015 from http://www.onlinelearningsurvey.com/reports/changingcourse.pdf 
2. Butler, T. J., \& Pinto-Zipp, G. (2005-2006). Students' learning styles and their preferences for online instructional methods. Journal of Educational Technology Systems, 34(2), 199-221.

3. Daymont, T., \& Blau, G. (2008). Student Performance in Online and Traditional Sections of an Undergraduate Management Course. Journal of Behavioral and Applied Management, 9(3), 275-294.

4. Dobbs, R. R., Waid, C. A., \& del Carmen, A. (2009). Students' Perceptions of Online Courses: The Effect of Online Course Experience. The Quarterly Review of Distance Education, 10(1), 9-26.

5. Downing, K., \& Chim, T. M. (2004). Reflectors as online extraverts? Educational Studies, 30(3), 265-276.

6. Drennan, J., Kennedy, J., \& Pisarski, A. (2005). Factors affecting student attitudes toward flexible online learning in management education. Journal of Educational Research, 98(6), 331-339.

7. Flynn, A., Concannon, F., \& Bheachain, C. N. (2005). Undergraduate students' perceptions of technologysupported learning: The case of an accounting class. ELearning, 4(4), 427-444.

8. Hannay, M., \& Newvine, T. (2006), Perceptions of Distance-Learning: A Comparison of Online and Traditional Learning. MERLOT Journal of Online Learning and Teaching, 2(1) 1-11. Retrieved March 12, 2015 from http://jolt.merlot.org/documents/MS05011.pdf

9. Howland, J., \& Moore, J. (2002), Student Perceptions as Distance Learners in Internet-Based Courses. Distance Education, 23(2), 183-195.

10. Kleinman, J. and E. Entin. Comparison of In-Class and Distance-Learning Students' Performance and Attitudes in an Introductory Computer Science Course," Journal of Computing Sciences in Colleges, 17:6, 2002, pp. 206219.

11. Kovacs, P.J., Davis, G.A., Scarpino, J.J., \& Kovalchick, L.L. (2011) Students’ Assessment of Online Learning as Related to Computer and Information Systems Curricula. Issues in Information Systems, XII(2), 13-21

12. Lu, J., C. Yu and C. Liu. "Learning Style, Learning Patterns and Learning Performance in a WebCTBased Course," Information and Management, 40, 2003, pp. 497-507.

13. McDonald, M., B. Dorn and G. McDonald. "A Statistical Analysis of Student Performance in Online Computer Science Courses," Proceedings of the 35th SIGCSE Technical Symposium on Computer Science Education, Norfolk, Virginia: 2004, pp. 71-74.

14. Means, B.; Toyama, Y.; Murphy, R.; Bakia, M.; Jones, K. (2009), Evaluation of Evidence-Based Practices in Online Learning: A Meta-Analysis and Review of Online Learning Studies October 11, 2010.

15. Picciano, A. (2002), Beyond Student Perceptions: Issues of Interaction, Presence, and Performance in an Online Course. Journal of Asynchronous Learning Networks, 6(1), 21-40.

16. Reeves, T., P. Baxter and C. Jordan. "Teaching Computing Courses - Computer Literacy, Business Microcomputer Applications and Introduction to Programming Online Utilizing WebCT," Journal of Computing Sciences in Colleges, 18:1, 2002, pp. 290-300.

17. Smith, P. J. (2005). Learning Preferences and Readiness for Online Learning. Educational Psychology, 25(1), 312.

18. Song, L., Singleton, E., Hill, J., \& Koh, M. (2004), Improving Online Learning: Student Perceptions and Challenging Characteristics. Internet and Higher Education, 7, 59-70.

19. Ury, McDonald, McDonald and Dorn (2006). "Student Performance Online vs Onground: A Statistical Analysis of IS Courses," Information Systems Education Journal, 4 (98).

20. Ury, G. (2005). "A Longitudinal Study Comparing Undergraduate Student Performance in Traditional Courses to the Performance in Online Course Delivery." The Information Systems Education Journal, 3(20). Retrieved February 18, 2015 from http://isedj.org/3/20

21. Wang, A. Y., Newlin, M. H., \& Tucker, T. L. (2001). A discourse analysis of online classroom chats: Predictors of cyber-student performance. Teaching of Psychology, 28, 222-226.

22. Zhao, Y., Lei, J., Yan, B., \& Tan, S. (2005). What makes the difference? A practical analysis of research on the effectiveness of distance education. Teachers College Record, 107(8), 1836-1884. 